Int. J. Electrochem. Sci., 16 (2021) Article ID: 210338

International Journal of

ELECTROCHEMICAL

SCIENCE

$\underline{\text { www.electrochemsci.org }}$

\title{
The Effect of Applying Magnetic Fields During Welding AISI- 304 Stainless Steel on Stress Corrosion Cracking
}

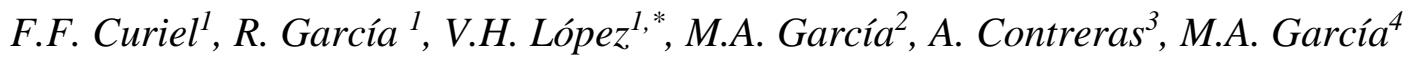 \\ ${ }^{1}$ Instituto de Investigación en Metalurgia y Materiales, Universidad Michoacana de San Nicolás de \\ Hidalgo, Edificio “U”, Ciudad Universitaria, Morelia, Mich., México, CP 58060. \\ ${ }^{2}$ Faculty of Metallurgy, Autonomous University of Coahuila, Carretera 57, km 5, Monclova, Coahuila, \\ México, CP 25720. \\ ${ }^{3}$ Instituto Mexicano del Petróleo, Eje Central Lázaro Cárdenas Norte 152, San Bartolo Atepehuacan, \\ México, C.P. 07730. \\ ${ }^{4}$ Centro Universitario de Ciencias Exactas e Ingenierías, Universidad de Guadalajara. Depto. de \\ Electrónica. 1421 Boulevard Marcelino García Barragán, Guadalajara, Jalisco, México, CP 44420. \\ *E-mail: vhlopez@umich.mx
}

doi: $10.20964 / 2021.03 .31$

Received: 20 October 2020 / Accepted: 24 December 2020 / Published: 31 January 2021

The stress corrosion cracking (SCC) behavior of AISI-304 stainless steel welded under the simultaneous application of electromagnetic fields of low intensity (0 to $28 \mathrm{mT}$ ) was studied. The plates were gas metal arc welded (GMAW) with an ER309L filler wire. The susceptibility to SCC was investigated using slow strain rate tests (SSRT) performed at strain rate of $1 \times 10^{6} \mathrm{~s}^{-1}$ in a glass autoclave containing a magnesium chloride solution $\left(20 \%-\mathrm{MgCl}_{2}\right)$ at room temperature and $80{ }^{\circ} \mathrm{C}$. Observation in the scanning electron microscope (SEM) showed that most of the specimens failed in the weld bead, exhibiting a ductile fracture with intergranular cracking. The SCC mechanism for welds of 304 stainless steel might be due to the formation of martensite at the grain boundaries. It was found that the magnetic field can modify the microstructure in the welded joints at a micro-level. This effect results in an improvement on the susceptibility to SCC. Secondary cracks were seen in the SSRT specimens in the SEM, most of them originated by pits. These features were more evident for the as-received 304 base metal and the $22 \mathrm{mT}$ welded joint tested at $80{ }^{\circ} \mathrm{C}$. The susceptibility to SCC increased at $80{ }^{\circ} \mathrm{C}$ as compared to ambient temperature. The welded joints that exhibited better resistance to cracking and pitting were specimens welded with magnetic fields of 9 and $28 \mathrm{mT}$.

Keywords: Stress Corrosion Cracking, Austenitic Stainless Steels, Welding, Magnetic Field. 
(C) 2021 The Authors. Published by ESG (www.electrochemsci.org). This article is an open access article distributed under the terms and conditions of the Creative Commons Attribution license (http://creativecommons.org/licenses/by/4.0/). 